\title{
Educating Children To Have Clear Vision In The Present Era
}

\author{
Mastha Ida Marpaung \\ \{masthaida@gmail.com\} \\ Postgraduate Program, Pelita Kebenaran School of Theology
}

\begin{abstract}
The first part in educating is making rules and delivering teachings. Rules must be made in the house. Teachers must make rules in class. Without regulations, children will get used to living wildly, living without rules, living as they wish, not willing to be regulated and become trouble makers. Simple rules should be made at home suitable to the age of the children. The first part in educating is making rules and delivering teachings. Rules must be made in the house. Teachers must make rules in class. Without regulations, children will get used to living wildly, living without rules, living as they wish, not willing to be regulated and become trouble makers. Simple rules should be made at home suitable to the age of the children. Parents who love their children will deliver teachings.

Keywords: Children, Vision, Educating
\end{abstract}

\section{Introduction}

In the present time, there several generations with different names, such as: generation without identity, lost generation, generation of drugs, generation of anarchy, generation of demonstrations, generation of "all I want", generation of terrorists, and others. Our question is why does this generation emerge, why are children born with such characters? It's not enough to just say they are influenced by the environment as this is not sufficient as an answer, Based in this, an observation was made of children with deviant behavior. What is the relationship with their parents or how their parents behave? There seems to be a connection. There is a causal relationship that we can investigate and it is possible to determine a clear relationship with the lives of their parents. If parents do not consciously prepare for the new generation, parents must educate children properly. The new generation should be a righteous people in the eyes of God. These people who are worthy are people whose families are right.

\section{Educating Children}

\subsection{Overview of Education}

Children are great imitators. The child will say what he hears and do what he sees. Parents' actions are followed by children. Therefore parents must give a good example to their children. Without role models, children start to be disappointed with their parents and this makes them lose their image, lose their figure, and begin to look at figures outside. How sad it is if the figure they imitate is not the right figure. Without example, advice and teaching loses power. Without example, children will not respect their parents. They must be a role model for others. Many 
people can be changed in the environment, including life partners and children by example. We cannot change much with rules and counsel from role models.

Lack of love, attention and time given by parents to children can lead to disappointment, heart break which can result in delinquency outside in order to get attention. If it is not immediately handled, this can develop into a rebellion. Children rebel because they want to express their identity and want to express their existence. Children want their existence to be considered, acknowledged by their existence, to be recognized as a person, not as a child.

Educating children is actually a simple path. There are only 3 main things:

1. Doctrine / rules

2. Punishment/disciplining children

3. Reward

1. Doctrine / Rules

The first part in educating is making rules and delivering teachings. Rules must be made in the house. Teachers must make rules in class. Without regulations, children will get used to living wildly, living without rules, living as they wish, not willing to be regulated and become trouble makers. Simple rules should be made at home suitable to the age of the children. Parents who love their children will deliver teachings. Educating is conveying teaching teachings, norms and values of life, rules, laws, and stories and experiences that contain education. The function and purpose of the teachings /rules is to make what is permissible or not should be clear doctrine / rules or law or order functions as a limitation of norms, ethics and manners. The function of the rule is a kind of law in the community or state. Arrange the rules at home / in class and tell the children gradually, according to the age of the child. This teaching will also make a child experience good maturity and emotional and social development.

2. Punishment / disciplining children

When should children be disciplined? They should be disciplined when they do things that violate the rules or the law. How long should the discipline for children be? In accordance with the function of punishment which is to make a mistake, if the child feels wrong then the punishing should be stopped. Children cannot feel and realize their mistakes by parents being angry and screaming. In educating children, giving education /punishment /disciplining children, the team of educators all involved in educating must have the same attitude, must be healthy including when punishing. Husbands and wives of parents and parents-in-law, parents, grandparents and even parents with nuns or assistants must be of one heart. Various forms of punishment / upbringing / disciplining children that can be applied include:

a. Scolding with words

b. Hit the buttocks

c. Making or flicking ears

d. Not given pocket money that week

e. Punishment works such as cleaning the room, etc.

3. Prizes / Rewards

Rewards/prizes provide acceptance, appreciation or appreciation, motivate people to do things and build personal relationships. Prizes amend hearts that are hurt by punishment and break rigidity because of the rules made. We give gifts when children do our rules /teachings. Various forms of rewards:

1. Praise

2. Goods

3. Promise 